\title{
Transplacental transmission of Anaplasma marginale in beef cattle chronically infected in southern Brazil
}

\author{
Transmissão transplacentária de Anaplasma marginale em bovinos \\ de corte cronicamente infectados no sul do Brasil \\ Hermann Eduardo Gonzalez Grau'; Nilton Azevedo da Cunha Filho; \\ Felipe Geraldo Pappen³; Nara Amélia da Rosa Farias ${ }^{1}$
}

\author{
${ }^{1}$ Laboratório de Parasitologia, Departamento de Microbiologia e Parasitologia, Universidade Federal de Pelotas - UFPel, \\ Pelotas, RS, Brasil \\ ${ }^{2}$ Programa de Pós-graduação em Veterinária, Universidade Federal de Pelotas - UFPel, Pelotas, RS, Brasil \\ ${ }^{3}$ Instituto Federal Catarinense - IFC, Concórdia, SC, Brasil \\ Received February 8, 2012 \\ Accepted March 5, 2013
}

\begin{abstract}
In this study, we have investigated the incidence of transplacental transmission of Anaplasma marginale in chronically infected cows with no history of acute anaplasmosis during gestation. In addition, we evaluated various techniques for detection of transplacental transmission of $A$. marginale. Blood samples were collected from 30 cows at three different periods: at the time of artificial insemination, at gestational diagnosis, and after calving. Also, blood was collected from the newborn calves, including one sample before colostrum intake, and another three days after birth. A. marginale-specific antibodies were detected in $100 \%$ of the cows with an indirect fluorescent antibody test (IFAT), and in $97 \%$ of them, using an indirect enzyme-linked immunosorbent assay (ELISA). Also, we observed that all of the three-day-old newborn calves were seropositive by IFAT. According to polymerase chain reaction, $63.3 \%$ of the cows were carriers of $A$. marginale, as well as $6.7 \%$ of the newborn calves. This represented a transplacental transmission rate of $10.5 \%$. Furthermore, a correlation of $93.3 \%$ was observed between the two serodiagnostic techniques, demonstrating that both ELISA and IFAT can be used in epidemiological surveys of $A$. marginale. These results confirm the occurrence of transplacental transmission of $A$. marginale in chronically infected cows and suggest the importance of this transmission route in areas of enzootic instability.
\end{abstract}

Keywords: Anaplasma marginale, transplacental transmission, enzootic instability.

\section{Resumo}

O objetivo do estudo foi avaliar a transmissão transplacentária de $A$. marginale em bovinos de corte cronicamente infectados utilizando diferentes testes de diagnóstico. Amostras de sangue foram colhidas de trinta matrizes durante o período de inseminação artificial, no diagnóstico de gestação e após o parto. Foi colhido sangue dos bezerros antes da ingestáo do colostro e três dias após o nascimento. Anticorpos foram detectados em 100\% das matrizes pela Reação de Imunofluorescência Indireta (RIFI) e 97\% pelo Ensaio de Imunoadsorção Enzimático Indireto (ELISA). Aos três dias de idade 100\% dos bezerros estavam soropositivos na RIFI. Conforme os resultados da PCR, 63.3\% das matrizes e 6.7\% dos bezerros eram portadores do agente, representando taxa de transmissão transplacentária de $10.5 \%$. Correlação de 93.3\% foi observada entre os resultados das técnicas sorológicas, demonstrando que tanto ELISA quanto RIFI podem ser utilizadas em levantamentos epidemiológicos do agente. Os resultados confirmaram a transmissão transplacentária do agente em vacas cronicamente infectadas. Isto demonstra a importância desta via de transmissão do $A$. marginale em áreas de instabilidade enzoótica.

Palavras-chave: Anaplasma marginale, transmissão transplacentária, instabilidade enzoótica.

\footnotetext{
*Corresponding author: Nilton Azevedo da Cunha Filho

Universidade Federal de Pelotas - UFPel, Rua Barra do Ribeiro, 15, Laranjal,

CEP 96090-060, Pelotas, RS, Brasil

e-mail: niltonacfilho@hotmail.com.br
} 


\section{Introduction}

Anaplasma marginale is a pathogen of the Rickettsiales order, family Anaplasmataceae (DUMLER et al., 2001), and is an obligate intraerythrocytic organism in vertebrates (KOCAN et al., 2000) that infects domestic and wild ruminants (KUTTLER, 1984). It causes jaundice, progressive anemia, weakness, and anorexia (REHBUN, 1995).

Anaplasmosis alone, or along with babesiosis, is responsible for significant economic losses in livestock farming worldwide, as it affects the performance of the cattle and limits their production. In fact, anaplasmosis causes death, weight loss, growth delay, low fertility in bulls, interference with the estrous cycle, and abortions (SWIFT et al., 1983; RIBEIRO; LIMA, 1996).

Enzootic stability to bovine anaplasmosis is found in most regions of Brazil (RIBEIRO; REIS, 1981; KESSLER et al., 1983), where at least $75 \%$ of nine-month-old cows show antibody seropositivity (MAHONEY; ROSS, 1972; GONÇALVES, 2000). In contrast, enzootic instability has been identified in the southern Rio Grande do Sul region, where $60-64 \%$ of nine-month-old cattle are seropositive for A. marginale (ARTILES et al., 1995; SILVA, 2003). This instability likely results from climate variations, leading to periods of low temperatures in which vector arthropods cannot reproduce.

The mechanisms of $A$. marginale transmission, as well as the epidemiologic importance of potential vectors, are very controversial (KESSLER, 2001; PYPERS et al., 2011). According to Kuttler (1984), A. marginale transmission does not occur transplacentally. However, other reports have suggested that transmission can occur when cows have acute anaplasmosis during gestation (ZAUGG; KUTTLER, 1984) or under conditions of constant inoculation in endemic areas (POTGIETER; VANRENSBURG, 1987; RIBEIRO et al, 1995).

Laboratory diagnosis of chronic anaplasmosis is performed via direct and indirect methods. The direct test involves identification of A. marginale DNA by polymerase chain reaction (PCR) and allows detection of parasitemia as low as $0.000025 \%$ in asymptomatic carriers (STILLER, 1992).

For indirect diagnosis, serological techniques are employed to detect antibodies against $A$. marginale. Indirect enzyme-linked immunosorbent assay (ELISA) is a widely used technique for detecting and/or quantifying antibodies in serum samples, especially during epidemiological studies (SOARES, 2001), showing a sensitivity of approximately 96.9\% (MADRUGA et al., 2000). Also, the indirect fluorescent antibody test (IFAT) continues to be one of the most used serological assays, displaying a sensitivity of approximately $97.2 \%$ (MADRUGA et al., 2000). The aim of the present study was to evaluate the occurrence of transplacental transmission of $A$. marginale in chronically infected beef cattle in areas of enzootic instability using various diagnostic tests.

\section{Materials and Methods}

\section{Study area and animals}

The study was carried out on a beef cattle farm (geographic coordinates: $31^{\circ} 45^{\prime} 48^{\prime \prime} \mathrm{S}$ and $52^{\circ} 29^{\prime} 02^{\prime \prime} \mathrm{W}$; average altitude: 21 meters). During initial screening, 50 Braford cows were selected for blood collection, and 60\% (30/50) of them were found to be seropositive for $A$. marginale. Thirty seropositive cows were included in the experiment, with deliveries occurring during the spring months (September and October). The cows were clinically followed throughout the gestational period by daily visual observation. Additional serological evaluations were performed at gestational diagnosis (during the third month of pregnancy) and three days after calving. The animals had been naturally exposed to ticks and hematophagous Diptera, as well as other handling procedures (injections and surgical procedures), which could be responsible for mechanical transmission. Moreover, the cows were not subjected to additional stress during the experiment.

\section{Collection of blood}

In order to obtain serum and packed red blood cells from animals, blood was collected in vacutainer tubes with and without ethylenediaminetetraacetic acid (EDTA). Samples were collected in a manner that did not interfere with the routine management procedures of the farm. For blood collection, either the coccygeal or jugular vein was punctured while the animals were in the corral of the farm. Blood samples were collected from the jugular veins of newborn calves before colostrum intake and then once again when they were three days old. All experimental animals were handled ethically. The collected material was kept at $4{ }^{\circ} \mathrm{C}$ and processed at the Laboratory of Parasitology of the Institute of Biology, Federal University of Pelotas. The serum was separated by centrifugation at $1,800 \times \mathrm{g}$ for 10 minutes at room temperature, and then stored at $-20^{\circ} \mathrm{C}$. Samples with EDTA were also centrifuged at $1,800 \times \mathrm{g}$ for 10 minutes, and the plasma and white cells were removed, leaving only the packed red blood cells. This material was kept in collection tubes to avoid contamination and was stored at $-20{ }^{\circ} \mathrm{C}$ until analysis at the Animal Health Laboratory of the Centro Nacional de Pesquisa em Gado de Corte (CNPGC) at EMBRAPA (Campo Grande, MS, Brazil).

\section{Serological tests}

\section{Indirect fluorescent antibody test (IFAT)}

Detection of $A$. marginale-specific IgG antibodies using IFAT was performed in accordance with Madruga et al. (2001). Antigens were prepared in the Protozoology and Animal Health Laboratory of the CNPGC at EMBRAPA. Serum and control samples were diluted at 1:160 in phosphate-buffered saline, $\mathrm{pH} 7.2$ (PBS), and fluorescein isothiocyanate (FITC)-labeled anti-bovine IgG (Sigma Chemical Company) was diluted at 1:160 in PBS. The IFAT was performed with the support of a Nikon Eclipse E400 microscope, and samples were considered positive when yellowgreen fluorescence was detected. 
Indirect enzyme-linked immunosorbent assay (ELISA)

ELISA-based testing for $A$. marginale-specific antibodies in bovine serum samples was performed by the Protozoology and Animal Health Laboratory of the CNPGC at EMBRAPA. The serum samples were diluted at 1:1,000 in PBS with $0.05 \%$ Tween 20. Absorbance was measured at $490 \mathrm{~nm}$ using a BIOTEK ELX 800 GIDX. Negative and positive controls were included on each plate. ELISA cut-off values were empirically determined using readings (mean $+3 \mathrm{SD}$ ) of serum samples of healthy cattle from tick-free areas in accordance with Madruga et al. (2000).

\section{Polymerase chain reaction (PCR)}

\section{Obtaining the DNA of $A$. marginale}

DNA extraction was carried out using the Easy DNA Kit according to the manufacturer's instructions (Invitrogen). The A. marginale msp5 gene (GenBank: M93392) was amplified using forward (5'-ATGAGAATTTTCAAGATTGTGTCTAACCTT-3') and reverse (5`-AGGAAAGCCCCCAAAGCCCCATACTT-3`) primers. For PCR, Taq DNA Polymerase (Invitrogen) was used, and the thermocycler conditions included 35 cycles $\left(94^{\circ} \mathrm{C}\right.$ 1 minute; $55^{\circ} \mathrm{C} 1$ minute; $72^{\circ} \mathrm{C} 1$ minute). PCR products were visualized using a $1 \%$ agarose gel, which was stained with ethidium bromide. The $1 \mathrm{~Kb}$ Plus DNA Ladder (Invitrogen) was used as the molecular size marker, and the amplified $m s p 5$ fragment was found to be $700 \mathrm{bp}$. Electrophoresis was performed at 80-90 V, and was stopped when the dye had migrated two-thirds of the gel length. Following electrophoresis, the gel was soaked in a solution of ethidium bromide $(0.5 \mathrm{~g} / \mathrm{mL})$ for $10-30$ minutes, and subsequently unstained in a water bath for 10-20 minutes. Bands were visualized using a UV transilluminator according to Araújo et al. (2002).

\section{Statistical analysis}

Sensitivity, specificity, predictive values (both positive and negative), and test accuracy were evaluated according to Coggon et al. (1993), using ELISA results as the gold standard. Comparisons between the prevalence of seropositive results detected by IFAT and ELISA techniques were performed by chi-square and Fischer's exact tests, with a confidence interval of $95 \%$. Statistical analyses were performed using Statistix 9.0 software (STATISTIX ${ }^{\circledR}, 2008$ ).

\section{Results}

All experimental cows (100\%) continued to test positive for A. marginale-specific antibodies by IFAT until the end of the experiment. In addition, three calves (10\%) were found to be seropositive at birth (before colostrum intake). Three days after birth, when the test was repeated, $100 \%$ of newborn calves were found to be positive.

The results obtained by ELISA (at the dilution tested) indicated that a total of 29 cows (97\%) were seropositive. However, no antibodies were detected by ELISA in the samples from the newborn calves. The sera collected three days after birth were not tested by ELISA. Considering all of the test results from the 60 serum samples (30 cows and 30 calves), the rates of seropositivity by IFAT and ELISA were 55\% and 48.3\%, respectively. Moreover, the difference between these values was not statistically significant $(\mathrm{p}>0.05)$ in the chi-square test (Table 1$)$.

The index of co-positivity was 100\% (29 samples were both ELISA $^{+}$and IFAT $^{+}$) and co-negativity was $87.1 \%$ (27 samples were ELISA $^{-}$and IFAT $^{-}$), which according to Coggon et al. (1993), corresponded to a concordance of $93.3 \%$ between the two tests (Table 2). A separate analysis of the results from only the adult animals revealed a concordance of $96.6 \%$ between the two techniques (ELISA and IFAT), whereas analysis of the data from the calves yielded a concordance of $90 \%$.

Using the Kappa Index according to Smith (1995), we obtained a value of 0.93 , which demonstrated almost perfect concordance between the two tests. To determine sensitivity and specificity of IFAT, it was compared to the ELISA test, which was considered to be the gold standard because it presents high specificity and produces few false positive results (MARANA et al., 2009; BRAZ et al., 2000).

A total of 19 of the 30 cows were positive (63.3\%) for A. marginale by PCR. Also, examination of calves at birth revealed that 2 out of $30(6.7 \%)$ were infected. These results indicated that the transplacental transmission rate detected by PCR was $10.5 \%$ (2/19). Notably, antibodies against $A$. marginale were detected by IFAT in $10 \%(3 / 30)$ of newborn calves. Thus, $A$. marginale DNA was detected in $66.7 \%(2 / 3)$ of the seropositive newborn calves $\left(\right.$ IFAT $\left.^{+}\right)$.

Table 1. Results of IFAT and ELISA tests for $A$. marginale in the serum of 30 cows and 30 calves at birth, in beef cattle chronically infected in southern Brazil.

\begin{tabular}{|c|c|c|c|c|c|c|}
\hline & \multicolumn{3}{|c|}{ IFAT } & \multicolumn{3}{|c|}{ ELISA } \\
\hline & Positive & Negative & \%Positive & Positive & Negative & \%Positive \\
\hline $\begin{array}{l}\text { Total } \\
(\mathrm{n}=60)\end{array}$ & 33 & 27 & 55 & 29 & 31 & 48.3 \\
\hline $\begin{array}{l}\text { Cows } \\
(\mathrm{n}=30)\end{array}$ & 30 & 0 & 100 & 29 & 1 & 96.7 \\
\hline $\begin{array}{l}\text { Calves } \\
(\mathrm{n}=30)\end{array}$ & 3 & 27 & 10 & 0 & 30 & 0 \\
\hline
\end{tabular}

The diference between the occurrence detected by both tests for each animal category and the two categories together were not statistically significant $(\mathrm{p}>0.05)$. 
Table 2. Results and validity analysis of IFAT tests for $A$. marginale in the serum of 30 cows and 30 calves at birth in relation to ELISA (gold standard) in beef cattle chronically infected in southern Brazil.

\begin{tabular}{lccc}
\hline \multirow{2}{*}{ ELISA } & \multicolumn{3}{c}{ IFAT } \\
\cline { 2 - 4 } & Positive & Negative & Total \\
\hline Positive & $29^{\mathrm{a}}$ & $0^{\mathrm{b}}$ & 29 \\
Negative & $4^{\mathrm{c}}$ & $27^{\mathrm{d}}$ & 31 \\
Total & 33 & 27 & 60 \\
\hline
\end{tabular}

According to Coggon et al. (1993):Sensitivity: a / $(a+c)$ x $100=87.9 \%$; Specificity: d / $(\mathrm{b}+\mathrm{d}) \times 100=100 \%$; Predictive Value $(+): \mathrm{a} /(\mathrm{a}+\mathrm{b}) \times 100=100 \%$; Predictive Value (-): d / (c+d) x $100=87.1 \%$; Accuracy: $(a+d) /(a+b+c+d)$ $\mathrm{x} 100=93.3 \%$.

\section{Discussion}

The experimental year (2007) presented favorable weather conditions for the development of hematophagous Diptera and ticks during autumn, spring, and summer. However, unfavorable weather conditions were observed from May to August, with temperatures lower than $15^{\circ} \mathrm{C}$, even though relative humidity (RH) of the air was higher than $80 \%$. During spring, weather conditions once again became favorable for the vectors, as $\mathrm{RH}$ ranged from $72.2 \%$ to $84.6 \%$, and mean temperature was between $16.2^{\circ} \mathrm{C}$ and $21.7^{\circ} \mathrm{C}$.

The results obtained in the initial screening test by IFAT, showed that only $60 \%$ of cows had antibodies against $A$. marginale. This prevalence was also found in areas of enzootic instability (MAHONEY; ROSS, 1972), as demonstrated by Artiles et al. (1995) and Silva (2003). Only seropositive cows were selected for this study, as the aim was to evaluate transplacental transmission of A. marginale in chronically infected beef cattle. The transplacental transmission rates detected by PCR and IFAT in this study were in agreement with those previously reported by Potgieter and Vanrensburg (1987), who studied animals with chronic infection and reported a transplacental transmission rate of $12.5 \%$ using a card agglutination test (CAT). In Brazil, Ribeiro et al. (1995) also reported transplacental transmission of $A$. marginale in fetuses during the second and third of gestation in endemic areas, identifying a rate of $2.1 \%$ by ELISA. Therefore, our data might indicate that the incidence of transmission is higher at the end of gestation, which could result from increased time for transmission. However, this finding could also be due to the fact that the older fetuses become immunologically competent allowing seropositivity.

Our observed concordance between the serological tests is similar to that previously determined by Madruga et al. (2000) (96\%), in which ELISA was used to detect antibodies against A. marginale of initial corpuscles obtained from splenectomized calves (80\% displaying rickettsial co-infection).

In the present study, ELISA results did not indicate transplacental transmission of $A$. marginale because no immunoglobulins could be detected in any calves at birth. This finding may have resulted from a low concentration of circulating antibodies in these newborn calves. In this regard, it is possible that the high dilution of sera used in our tests (1:1,000 at ELISA, and 1:160 at IFAT) could have contributed to these negative results.
Here, all newborn calves were positive by IFAT three days after birth. This finding shows the efficacy of immunoglobulin transmission through colostrum. These data are in agreement with a study by Silva (2003), which reported $100 \%$ transmission of immunoglobulins via colostrum in newborn calves aged 5 and 15 days in a herd under similar epidemiological conditions to those of our experiment.

The fact that one animal was found negative by PCR, whereas all samples had tested positive by IFAT, probably indicates a false positive serum result. This finding likely stems from the specificity of IFAT, which is not 100\% (BRAZ et al., 1997). This hypothesis is confirmed by the fact that techniques based on DNA amplification display high sensitivity and specificity and are capable of identifying animals with extremely low parasitemias, like carriers and asymptomatic young calves (BRITO et al., 2007).

\section{Conclusion}

This study demonstrated that even in an area of enzootic instability, cows chronically infected with $A$. marginale, without a history of acute anaplasmosis during gestation, could infect offspring transplacentally. Moreover, all cows serologically positive for $A$. marginale transferred antibodies to their offspring via colostrum at levels detectable by IFAT. Taken together, we have shown that IFAT and ELISA are efficient for indirect diagnosis of $A$. marginale infection in cattle, particularly in epidemiological surveys.

\section{References}

Araújo FR, Santos LR, Madruga CR, Fragoso SP, Umaki ACS, Soares CO. Clonagem e expressáo do gene msp5 de um isolado brasileiro de Anaplasma marginale. Campo Grande: Embrapa Gado de Corte; 2002. Circular Técnica n. 29.

Artiles J, Alves-Branco FPJ, Martins JR, Correa LB, Sapper MFM. Prevalência de Babesia bovis, Babesia bigemina e Anaplasma marginale no município de Bagé, RS. Braz J Vet Parasitol 1995; (S1): 179.

Braz CJ Jr, Passos LMF, Lima JD, Ribeiro MFB. Comparison between ELISA and Indirect Fluorescent Antibody Test in the detection of antibodies against Anaplasma marginale in cattle. Arq Bra Med Vet Zootec 1997; 49 (5): 543-549.

Braz CJ Jr, Ribeiro MFB, Lima JD, Passos LMF. Development of an ELISA System for detection of anti-Anaplasma marginale antibodies in cattle in Brazil. J Vet Med B Infect Dis Vet Public Health 2000; 47(4): 241-248. http://dx.doi.org/10.1046/j.1439-0450.2000.00342.x

Brito LG, Oliveira MCS, Netto FGS, Rocha RB, Cavalcante FA, Marim AD, et al. Epidemiologia molecular de Anaplasma marginale em bovinos criados nos estados de Rondônia e Acre. Porto Velho: Embrapa Rondônia; 2007. Boletim de Pesquisa e Desenvolvimento n. 49.

Coggon T, Rose G, Barker DJ. Measurement, error and bias. In: Coggon T, Rose G, Barker DJ, editors. Epidemiology for the Uninitiated. 3rd ed. London: BMJ Publishing Group; 1993. p. 20-25.

Dumler JS, Barbet AF, Bekker CPJ, Dash GA, Palmer GH, Ray $\mathrm{SC}$, et al. Reorganization of genera in the families Rickettsiaceae and Anaplasmataceae in the order Rickettsiales: unification of some species 
of Ehlrlichia with Anaplasma, Cowdria with Ehrlichia and Ehrlichia with Neorickettsia, descriptions of six new species combinations and designation of Ehrlichia equi and 'HGE agent' as subjective synonyms of Ehrlichia phagocytophila. Int J Syst Evol Microbiol 2001; 51(4): 2145-2165. PMid:11760958. http://dx.doi.org/10.1099/00207713-51-6-2145

Gonçalves PM. Epidemiologia e controle da tristeza parasitária bovina na região sudeste do Brasil. Cienc Rural 2000; 30(1): 187-194. http:// dx.doi.org/10.1590/S0103-84782000000100030

Kessler RH. Considerações sobre a transmissão de Anaplasma marginale. Pesq Vet Bras 2001; 21(4): 177-179. http://dx.doi.org/10.1590/S0100736X2001000400009

Kessler RH, Madruga CR, Shenck MAM. Babesiose cerebral por Babesia bovis (Babes, 1888, Starcovici, 1983) em bezerros do estado do Mato Grosso do Sul. Pesq Agropec Bras 1983; 22: 1225-1230.

Kocan KM, Blouin EF, Barbet AF. Anaplasmosis control: past, present and future. Ann NY Acad Sci 2000; 916(1): 501-509. PMid:11193665. http://dx.doi.org/10.1111/j.1749-6632.2000.tb05329.x

Kuttler KL. Anaplasma infections in wild and domestic ruminants: a review. J Wildl Dis 1984; 20(1): 12-20. PMid:6716555.

Madruga CR, Marques APC, Leal CRB, Carvalho CME, Araújo FR, Kessler RH. Evaluation of an enzyme-linked immunosorbent assay to detect antibodies against Anaplasma marginale. Pesq Vet Bras 2000; 20(3): 109-112. http://dx.doi.org/10.1590/S0100736X2000000300004

Madruga CR, Araújo FR, Soares CO. Imunodiagnóstico em Medicina Veterinária. Campo Grande: Embrapa Gado de Corte; 2001. 369 p.

Mahoney DF, Ross DR. Epizootiological factors in the control of bovine babesiosis. Aust Vet J 1972; 48(5): 292-298. PMid:4672119. http:// dx.doi.org/10.1111/j.1751-0813.1972.tb05160.x

Marana ERM, Kano FS, Vicentini JC, Spurio RS, Ribeiro M, Coelho ALM, et al. Clonagem, expressão, caracterização molecular da proteína de superfície MSP 5 da amostra PR1 de Anaplasma marginale e sua aplicação em um teste de ELISA por competição. Braz J Vet Parasitol 2009; 18(2): 5-12. http://dx.doi.org/10.4322/rbpv.01802002

Pypers AR, Holm DE, Williams JH. Fatal congenital anaplasmosis associated with bovine viral diarrhoea virus (BVDV) infection in a cossbreed calf. JSAVA 2011, 82 (3): 179-182.
Potgieter FT, Vanrensburg L. The persistence of colostral Anaplasma marginale antibodies and incidence of in utero transmission of Anaplasma infections in calves under laboratory conditions. Onderstepoort J Vet Res 1987; 54(4): 557-560. PMid:3444609.

Rehbun WC. Diseases of Dairy Cattle. Ithaca: Williams \& Wilkins; 1995.530 p.

Ribeiro MFB, Reis R. Natural exposure of calves to Anaplasma marginale in endemic areas of Minas Gerais. Arq Esc Vet UFMG 1981; 33(1): 63-66.

Ribeiro MFB, Lima JD, Guimarães AM, Scatamburlo MA, Martins NE. Transmissão congênita da anaplasmose bovina. Arq Bras Med Vet Zootec 1995; 47(3): 297-304.

Ribeiro MFB, Lima JD. Morphology and development of Anaplasma marginale in midgut of engorged female ticks of Boophilus microplus. Vet Parasitol 1996; 61(1-2): 31-39. http://dx.doi.org/10.1016/03044017(95)00800-4

Silva GAC. Anaplasma marginale (THEILER, 1910): Imunidade passiva e ativa em bovinos nascidos na primavera no sul do Rio Grande do Sul [Dissertação]. Pelotas: Universidade Federal de Pelotas; 2003.

Smith RD. Veterinary Clinical Epidemiology: A problem-oriented approach. 2nd ed. CCR Press; 1995.

Soares CO. Princípios, padronização e validação de provas sorológicas. In: Madruga CR, Araújo FR, Soares CO. Imunodiagnóstico em Medicina Veterinária. Campo Grande: Embrapa Gado de Corte; 2001. p. 145-175.

Statistix ${ }^{\circledR}$. Statistix 9. Analytical software. Tallahassee; 2008.

Stiller D. Biotechnology: a new approach to the diagnosis and control of tick-borne hemoparasitic diseases. Ann N Y Acad Sci 1992; 653: 19-25. PMid:1352669. http://dx.doi.org/10.1111/j.1749-6632.1992. tb19625.x

Swift BL, Johnson RW, Thomas GM. Anestrus in cycling beef heifers experimentally inoculated with Anaplasma marginale. Theriogenology. 1983; 20(6): 715-724. http://dx.doi.org/10.1016/0093691X(83)90192-9

Zaugg JL, Kuttler KL. Bovine anaplasmosis: in utero transmission and the immunologic significance of ingested colostral antibodies. Am J Vet Res 1984; 45(3): 440-443. PMid:6711971. 